\title{
Development of Waqf Forest in Indonesia: The SWOT-ANP Analysis of Bogor Waqf Forest Program by Bogor Waqf Forest Foundation
}

\author{
Khalifah Muhamad Ali ${ }^{1,2^{*}}$, Salina Kassim ${ }^{2}$ \\ ${ }^{1}$ Department of Islamic Economics, IPB University, Bogor, Indonesia 16680 \\ ${ }^{2}$ Institute of Islamic Banking and Finance, International Islamic University Malaysia, Gombak, Malaysia 53100
}

Received January 19, 2021/Accepted June 23, 2021

\begin{abstract}
Some communities and governments in Indonesia have taken the initiative to develop waqf forests to solve forest conservation problems. However, research on waqf forest development is still rarely studied. This study aims to improve the strategy of waqf forest development in Indonesia. SWOT method is used to identify the strengths, weaknesses, opportunities, and threats and the possible development strategies of the Bogor Waqf Forest as a manager of Waqf Forest. The ANP method prioritizes these four aspects and the best strategy in developing the waqf forest. An aggressive strategy needs to be carried out by optimizing the existing legal organization and the welleducated human resources to inform the public about the waqf concept in Islam and its application in the waqf forest. Thus, the vast potential of cash waqf and waqif can be obtained. This paper is one of the pioneering articles that discuss waqf forest development strategies, especially in Indonesia. From this research, we recommend the Bogor Waqf Forest to resolve the legal aspects as an official waqf manager, and the government and Indonesian Ulema Council to issue regulation and fatwa regarding waqforest.
\end{abstract}

Keywords: ANP, SWOT, waqf, waqfforest

*Correspondence author, email: khalifahma@apps.ipb.ac.id,tel.+62 2518624120

\section{Introduction}

Indonesia has the third-largest tropical rainforest in the world after Brazil and Congo (Alisjahbana \& Busch, 2017). Unfortunately, the forest area in Indonesia has tended to decline since 1990. From 2019 until $12^{\text {th }}$ December 2019, the Ministry of Environment and Forestry of Indonesia recorded at least 942,484 ha of forests in Indonesia reduced due to forest fire (Indraswari, 2020). It does not include a decrease in forest area due to forest conversion.

Forest destruction that does not only occur in state forests but also community forests mainly due to massive logging (Rasyid, 2014) is endangering agricultural production (Yamamoto et al., 2019) and all humanity's lives. In the context of the SDGs, this damage makes poverty increase due to climate change, starvation due to loss of sources of water and insects, respiratory problems due to smoke from forest fires, and destruction of infrastructure due to floods and landslides. All of that can interfere with the SDGs goals (Seymour \& Busch, 2016).

Islam, a perfect religion and covers all aspects of life, certainly has a solution to this problem. Islam is not only a ritual religion that regulates the relationship of servants with Allah but also a faith that pays attention to the relationship between humans and other humans and their environment, including forests.

Allah has ordered humans to protect the environment, including the forests, and has warned humans not to damage it. The word "tree" has been mentioned in the Qur'an 26 times
(Ozdemir, 2002), for example, in Surah Ibrahim verse 24-25 (Saheeh International Translation, 2010):

Have you not considered how God presents an example, [making] a good word like a good tree, whose root is firmly fixed and its branches [high] in the sky?

Rasulullah said, "Whoever cuts down a lote-tree, Allah will put his head in the fire.". Imam Abu Dawud explained this noble hadith in his book,

"Whoever cuts down a lote-tree in the wilderness under which wayfarers and animals find shades, for no purpose or unlawfully, Allah will put his head in the Fire." (AbuDawud, 2008).

In the Arab tradition, lote-tree (as-sidrah) is commonly used to represent all trees. The tree often grows in the middle of the desert, so it is very beneficial for travelers to shelter (Qaradhawi, 2001). Therefore, cutting down trees without the right reasons is to disperse the Prophet's orders. Instead, the Prophet encouraged his people to plant trees. In a hadith, the Prophet said,

Narrated Anas bin Malik: Allah's Apostle said, "There is none amongst the Muslims who plants a tree or sows seeds, and then a bird, or a person or an animal eats from it but is regarded as a charitable gift for him." (Sahih Bukhari, 2009)

Waqf (Islamic Endowment), as one of the main instruments in Islamic social finance, has the potential to be a 
solution to environmental problems (Al-Anzi \& Al-Duaij, 2004) and forest destruction. Management of waqf, which was limited to socio-religious activities, began to shift towards maintaining and preserving the environments.

Some communities and governments in Indonesia have taken the initiative to develop waqf forests as forest conservation efforts (Ali, 2019). The first waqf forest in Indonesia was established in Aceh Province in 2012 called "Hutan Wakaf Jantho" (Waqf Forest Jantho). They invited people to donate as cash waqf and use it for buying critical land and convert the purchased land to waqf forest. The area will be converted to a waqf forest (Hutantersisa.org, 2018). Waqf forests were also have been built in Bandung Regency in 2013 called "Wakaf Leuwueng" (BWI, 2010). "Leuwueng" in Sundanese means "forest". In Bogor Regency, West Java, the waqf forest was developed in 2018 named "Hutan Wakaf Cibunian" due to located in Cibunian Village, Pamijahan District (Ali \& Kassim, 2020) .

Previous research by Budiman (2011) stated that waqf could maintain the sustainability of the environment. More specifically, Yaakob et al. (2017) indicated that waqf could be announced as an alternative to forest conservation and regeneration program. In line with that, Hasanah \& Hakim (2017) also mentioned that cash waqf could be used to bought an area in the city and managed as an urban forest. Also, Setyorini et al. (2020) argue that the waqf for the environment is similar to another donation for environmental sustainability. However, it is run and managed according to Islamic principles. Moreover, Ali and Kassim (2020) specifically mentioned that the waqf program could be used to finance and manage a forest by addressing the concept of waqf forest. Based on those articles, we can conclude that as an Islamic social finance instrument, waqf can be used as a potential and prospective source of funding for saving the tropical rain forests in Indonesia.

However, research on waqf forests development is still rarely studied. Therefore, this study aims to improve the strategy of waqf forest development. It includes exploring the strengths, weaknesses, opportunities, and threats from Bogor Waqf Forest Foundation as the waqf manager to choose the best strategy using the analytic network process (ANP) method. Bogor Waqf Forest Foundation is a nazir (waqf manager) that focuses on developing productive waqf forests in Bogor, West Java, Indonesia. The foundation raises public funds to buy community-owned land. The purchased land is converted into waqf forest and managed productively ecologically and economically. To our knowledge, this paper is one of the pioneering articles that provides a discussion of waqf forest development strategies from the perspective of nazir, especially in Indonesia.

This paper is divided into five sections. The first is the introduction, stated about the background and previous related researches about the topic, followed by the research gap and objective. Next is the methodology, mainly reported about the SWOT-ANP analysis as the method used in this research. The third is result and discussion, explained in detail about every SWOT aspect, and Bogor Waqf Foundation's strategies in developing a waqf forest. Then, it followed by a conclusion and ended with policy recommendations.

\section{Methods}

This study uses an analytic network process (ANP) approach. ANP is a primary tool used to help organize thoughts (Saaty \& Vargas, 2006) to the decision process. ANP, which was first introduced by Saaty in 1980, is developing the analytic hierarchy process (AHP) because many decision problems cannot be structured hierarchically (Saaty \& Vargas, 2006).

ANP is suitable to be the approach for this research because ANP can provide a framework along with priority values in every aspect. The priority values are generated through mathematical calculations for each element (nodes) as the basis for decision/conclusion/strategy making. The ANP approach can also identify the most significant problems and find the best solutions and strategies for solving them. The example of using ANP in waqf is research by Ali et al. (2018), which identifies waqf problems in Indonesia. The other example is the work by Ali et al. (2020), which investigates Islamic financial inclusion determinants in Indonesia.

ANP can be integrated with other frameworks because, in ANP, researchers are given the freedom to determine their aspects according to the research topic. In terms of developing an organization, the ANP approach, which is synergized with SWOT, is commonly used in research in various fields. For example, Khotimah et al. (2017) used a strategy for developing small and medium enterprises (SME). In this case, ANP plays a role in providing a math framework, while SWOT plays a role in delivering essential aspects that need to be developed in anorganization's development. This aspect consists of internal organizations containing strengths and weaknesses and external elements containing opportunities and threats. ANP research consists of 3 phases: model construction, quantification models, synthesis, and analysis (Ascarya, 2012).

Model construction Model construction is to develop the model of the ANP framework. In this phase, the researcher, who is the developer of the waqf forest, compiles a model based on personal experience in developing the waqf forest that he manages, which is located in Cibunian Village, Pamijahan District, Bogor Regency, West Java, Indonesia. Apart from being based on personal experience, the researcher also developed an ANP model based on discussions with other waqf forest developers and experts in developing waqf forests. Moreover, model construction is also based on literature reviews in journals, books, magazines, and online articles. The ANP framework formed was used as the basis for the preparation of the research questionnaire.

This study applies a simplified pairwise questionnaire, as in the survey conducted by Ascarya (2005). A simplified pairwise questionnaire is intended to reduce the consistency index (CI) level so that it remains below the allowable limit $(10 \%)$, which is likely to occur due to the number of questions a respondent has to answer. Besides, simplified questionnaires will also improve the interview time's efficiency, which is an important aspect that must be considered to get consistent responses from respondents. 
Model quantification The second stage is the quantification of the model. At this stage, the researcher met the respondents who were considered the most knowledgeable person on the topic. Respondents are divided into three categories, namely: academics, practitioners and regulators. In the ANP research, the number of respondents is not limited to a certain amount. However, the number of informants who are not even (odd) will facilitate calculating the geometric mean, which will be explained in the text description. The profile of each respondent is presented in Table 1 .

Waqf experts make pairwise comparisons between two elements to find out which one is more important. Each expert is given a questionnaire that has been formed based on the first research stage. Each expert filled out their questionnaires by making a pairwise comparison. Each expert was asked to give a score ranging from 1 to 9 on each question in practice (Table 2).

Number 1 indicates that the two things being compared are equally important, 3 shows moderate importance of one over another, 5 shows strong or essential importance, 7 shows very strong or demonstrated importance, and 9 is extreme importance. While the numbers 2, 4, 6, 8 indicate intermediate values (Table 2). Pairwise comparisons data are then collected and inputted into the "Super Decisions" software. ANP is now used fairly widely by decision-makers, consultants, teachers, and students in business and engineering schools (Saaty \& Vargas, 2006).

Synthesis and analysis After quantifying the model, the next step is the analysis and synthesis of the results. All of the data inputted into the model built in the first stage will be synthesized in this stage. Three types of output data will be generated at this stage: priority, geometric mean data, and rater agreement.

a. Priority is data that shows the ranking of each cluster. This data can be directly obtained through the help of
Super Decisions software. When all pairwise comparisons have been completed in a model, to get this priority data, it can be done by clicking the Computations tab, then Priorities.

b. The second data generated from the analysis and synthesis stage is the geometric mean (GM). Each respondent has a model. It is necessary to do further data processing by finding the geometric mean to unite the respondents' opinions. The geometric mean value cannot be obtained directly from the Super Decisions software, but it must carry out further data processing. It is necessary to input all pairwise comparison data from all respondents to calculate the geometric mean value. After all of the data has been coded in a table, the data inversion process is carried out. Then, the inverse data is entered into the geometric mean formula.

The geometric mean (GM) value is an indicator used to see the combined opinions of all experts selected in the study. Previously to see the combined views of the experts, what was done was to look at the mean (mean) of all existing ideas. GM values cannot be directly obtained from the Super Decisions software but must be processed further using Microsoft Excel software.

c. The third (final) data generated from the analysis and results stage is the rater agreement. Rater agreement is an indicator that shows the level of understanding of experts of the research, which in this study is the agreement of waqf experts on the development of waqf forests in Indonesia. The rater agreement data is expressed by the Kendall Coefficient of Concordance, denoted by the letter "W." The Kendall coefficient ranges from 0 to 1, inwhich 1 (one) shows the perfect agreement and conversely, 0 (zero) indicates absolute disagreement (Ascarya, 2005). According to Ascarya (2005), the opinions of experts have been considered quite agreeable if the value of W is more than 0.4. However, that does not mean that if W's

Table 1 ANP respondent profile

\begin{tabular}{|c|c|c|}
\hline Name & Capacity & Institute \\
\hline AA & Practitioner & $\begin{array}{l}\text { Founder of Bogor Waqf Forest Foundation and Professor of the Faculty } \\
\text { of Forestry and Environment of IPB }\end{array}$ \\
\hline IA & Practitioner & Founder of Bogor Waqf Forest, in Bogor, West Java \\
\hline $\mathrm{FN}$ & Regulator & $\begin{array}{l}\text { Director-General of Zakat and Waqf Empowerment, Ministry of } \\
\text { Religion of the Republic of Indonesia }\end{array}$ \\
\hline HT & Regulator & Head of the Nazir Coaching Division of Indonesia's Waqf Board (BWI). \\
\hline IS & Academia & IPB University, Director of BAZNAS \\
\hline AN & Academia & IPB University \\
\hline $\mathrm{NH}$ & Academia & University of Indonesia \\
\hline
\end{tabular}

Table 2 Scaling guidance (Source: Saaty \& Vargas, 2006)

\begin{tabular}{ll}
\hline Scale & Judgments \\
\hline 1 & Equal importance \\
3 & Moderate importance of one over another \\
5 & The strong or essential importance \\
7 & Very strong or demonstrated importance \\
9 & Extreme importance \\
$2,4,6,8$ & Intermediate values \\
\hline
\end{tabular}


value is below 0.4 , then the model is wrong or useless. The Kendall coefficient is used only to show the level of agreement of the experts, not to judge the merits of a model. The rater agreement cannot be obtained directly from the Super Decisions software. Some steps need to be done, namely transpose, ranking, and $\mathrm{W}$ calculation with a specific formula. The $\mathrm{W}$ value cannot be directly obtained from the Super Decisions software, but through semi-manual data processing, processed with Microsoft Excel software. Three steps need to be done to get the value of W, namely transpose, ranking, and calculation.

\section{Results and Discussion}

The focus of the study was the Bogor Waqf Forest Foundation as the manager of the Bogor Waqf Forest. Although there have been several waqf forest managers in Indonesia, it is known that the Bogor Waqf Forest Foundation is one of the official waqf forest managers in Indonesia. In short, the Bogor Waqf Forest Foundation is a foundation that focuses on the development of waqf forests located in Bogor Regency, West Java, Indonesia. The Bogor Waqf Forest Foundation, formerly Yassiru Foundation, was established in 2014.

The Bogor Waqf Forest Foundation received a waqf land in Kampung Muara 1, Cibunian Village, Pamijahan District, Bogor, West Java, Indonesia. This land later became the first land of the Bogor Waqf Forest. At present, the Bogor Waqf Forest Foundation is managing a 6,530 square meter waqf forest. The latest waqf forest location was established after the Bogor Waqf Forest Foundation raising more than IDR 50 million waqf funds from more than 40 waqif in Ramadhan $1441 \mathrm{H}$. In the future, they will continue to expand waqf

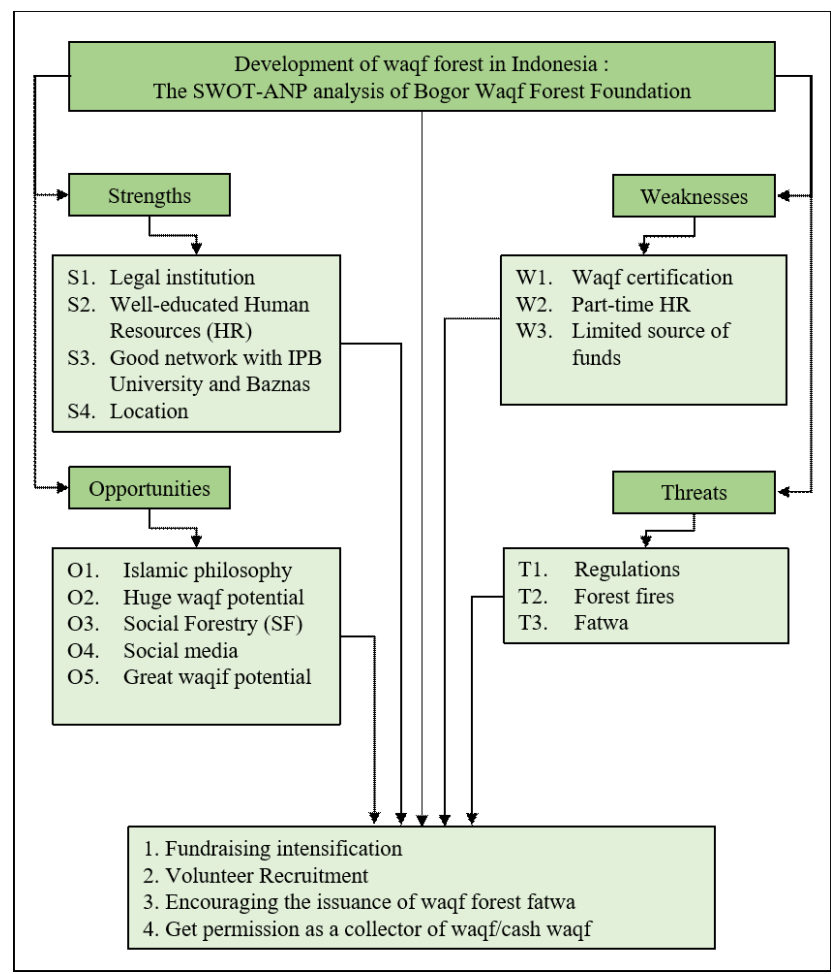

Figure 1 The ANP-SWOT framework. forests, thus providing broader ecological and economic benefits for the community and its environment. The SWOTANP model for Bogor Waqf Forest Foundation can be seen in Figure 1.

Strength There are four aspects of strength: legal institutions, well-educated human resources, location, and good networking with IPB University and BAZNAS. Based on the results of in-depth interviews with experts (Figure 2), the most important aspects of strength are legal institutions (42.4\%), followed by well-educated Human Resources (HR) $(22.7 \%)$ and location $(22.7 \%)$, and finally, good networking with IPB University and BAZNAS (12.2\%). Kendall's coefficient $(\mathrm{W})$ is 0.53 ; it means that respondents tend to agree on the priority aspects of strength in the development of the Bogor Waqf Forest Foundation.

The biggest strength is the legal institution. In line with the previous research from Khuza et al. (2019), they mentioned that the waqf institution's legal statement from BWI is critical to ensure the waqf assets' stability and sustainability. The Bogor Waqf Forest Foundation has an official institution recognized by the state by a Decree from the Ministry of Law and Human Rights, Republic of Indonesia Number AHU-0016834.AH.01.04.2020.

The next strength is well-educated human resources. Human resources are considered as strengths in an organization. Talented human resources with a good attitude, knowledge, personality traits and skills have a positive and significant relationship with managerial activities (Rastgoo, 2016). Most of the managers are professors and masters from various faculties at IPB University, namely the Faculty of Forestry, the Faculty of Agriculture, and the Faculty of Economics and Management. In its daily activities, the foundation is assisted by young people, namely undergraduate students from the Department of Islamic Economics, Faculty of Economics and Management IPB University, and alumni of the Islamic University of Madinah, Saudi Arabia.

The third strength is the waqf forest location, which is relatively more strategic than waqf forests such as waqf forest in Aceh or waqf forest in Bandung Regency. The Bogor Waqf Forest managed by Bogor Waqf Forest foundation is located in Bogor Regency, which is one of the

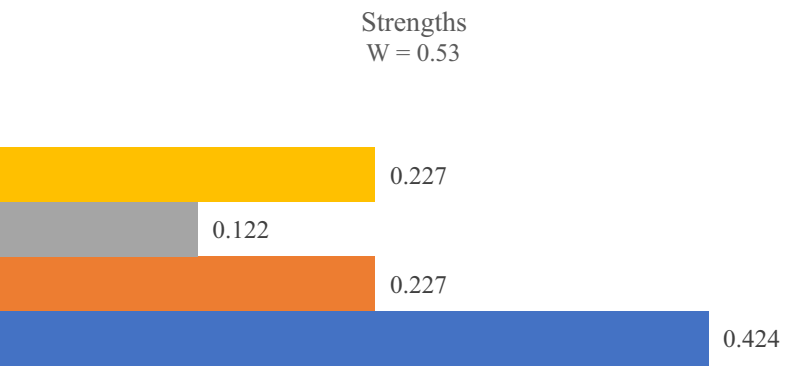

Location

- Good network with IPB and BAZNAS

- Well-educated HR

- Legal Institutions

Figure 2 Priority among the strength aspects. 
most populous districts in Indonesia and is located close to the National Capital City, DKI Jakarta. Waqf forests near the national capital are more likely to benefit economically, socially, and ecologically as they are closer to humans as the main mauquf'alaih. In terms of fundraising activities, community donations are predicted to be more significant because the location is more easily accessible by many people. In line with that, (Hörnsten, 2000) mentioned that the closer location of the forest, it will increase the desire of people to visit it without destroying it. Affordability is vital because many waqf or prospective waqf want to see the area before donating. However, some donors may give directly without visiting the location. A close and easy-access site will facilitate waqf managers and volunteers to optimize management activities in the management aspect. It is crucial because, as stated in the previous research by Shafiai et al. (2015), some idle land is because its location is far and hard to access. This location also plays an essential role in volunteer recruitment. For example, in the Bogor WaqfForest, there is a volunteer team of students from the Department of Sharia Economics, Faculty of Economics and Management, IPB University, as mentioned earlier.

A good network will have many positive impacts on organizational performance, including opening opportunities for organizations to work on more significant and impactful projects to improve organizational performance (Gibson et al., 2014). However, a good relationship between the Bogor Waqf Forest Foundation and IPB University and BAZNAS was considered the lowest strength $(12.2 \%)$. Therefore, the development of this foundation needs to be focused on the other strength aspects mentioned earlier.

Weaknesses Bogor Waqf Forest Foundation has three weaknesses: waqf certification, part-time human resources, and limited source of funds. Based on the results of in-depth interviews with experts (Figure 3), the biggest weakness is waqf certification $(55 \%)$, followed by part-time human resources $(24 \%)$ and limited source of funds $(21 \%)$. Kendall's coefficient score (W) is 0.55 . It shows that the experts agree on the priority of these weaknesses.

The waqf certification is considered as the most significant weakness $(55 \%)$. Despite having a registered official organization, the Bogor Waqf Forest Foundation has not been officially recognized by the state as cash waqf nazir, as mentioned in the Government Regulation concerning The

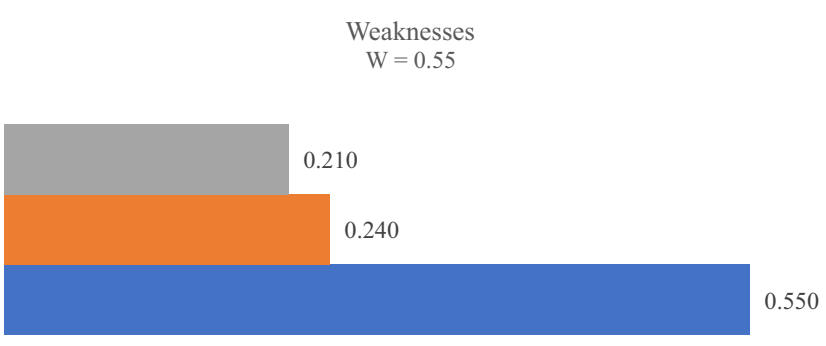

m Limitied source of funds $\square$ Part-time HR $\quad$ Waqf certification

Figure 3 Priority among the weakness aspects.
Implementation of Act Number 41 of 2004 on Waqf (Government Regulations Number 42, 2006). Based on existing regulations, the Bogor Waqf Forest Foundation has been allowed to collect awqaf, such as land or property. However, based on the interview with the experts, special permission is needed from The Ministry of Religious Affairs. The foundation needs to register the waqf asset and its nazir, who can manage the property.

The next priority of weakness is part-time human resources (24\%). Regarding human resources, Arredondosoto et al. (2019) mentioned that experience is one of the vital aspects of human resources. It can be obtained if the HRfocused on his job for some amount of time. Meanwhile, the waqf managers who work at the Bogor Waqf Forest Foundation do not work full-time. All foundation administrators work part-time, which means that they manage the foundation only in their free time. Part-time worker causes the foundation moving slowly. For example, both asset certification and cash waqf manager certification are slow because the foundation manager can only work on a part-time basis. The certification process is a process that involves many parties. Therefore, full-time work is needed.

The limited source of funds is considered as the lowest weakness (21\%). Bogor Waqf Forest Foundation has limited funds due to inadequate fundraising activities. However, the experts believe that the limited fund is not crucial. Almost every foundation starts with a limited source of funds. One of the experts confirmed that many social foundations had started their activities with limited funds. Therefore, instead of focusing on this weakness, it is better to focus on other aspects that can be optimized, for example the human resources. Based on Tuckman and Jensen (1977), there are five stages of organizational development based, namely forming, storming, norming, performing, and adjourning. The Bogor Waqf Forest Foundation, based on the current human resources condition, is still in the 'storming' stage, where the team is already formed, but their rules and responsibilities are still brainstormed. Strengthen the human resorces will have a positive impact on funding problems. Based on the experiences, limited funds can be circumvented through good networking. The fund's source will be available along with the high level of good relations and trust of prospective donors to the Bogor Waqf Forest Foundation.

Opportunities There are five identified opportunities: Islamic philosophy, huge waqf potential, social forestry, social media, and great waqif potential. Based on the results of in-depth interviews with experts (Figure 4), sequentially, the essential aspects of opportunities were Islamic philosophy $(28.3 \%)$, huge waqf potential $(27.6 \%)$, great waqif potential $(16.8 \%)$, social forestry $(14.1 \%)$, and finally is social media (13.2\%). Kendall's coefficient score (W) is 0.35 . It means that the respondents tend to disagree in this matter.

The waqf concept in Islamic philosophy is the foremost opportunity $(28.3 \%)$ that must be optimized. According to one of the experts, HT, waqf is "The original of Islamic Economics," which is an original Islamic religion concept. One of the oldest waqf assets that still exists is the Kaaba in Mecca, built by the Prophet Ibrahim (Rohmaningtyas \& 
Herianingrum, 2010). In Islam, waqf has a high position in the sight of Allah. Waqf is one of the best forms of worship to be close to Allah (As-Sa'di, 2002). Waqf is the perfection of a servant of Allah (as stated in the Holy Quran surah Ali Imran verse 92). Waqf is alms that the rewards keep flowing even though waqif has passed away, narrated in hadith Muslim (Sahih Muslim, 2009), yet the waqf rewards can also be sent to parents/families who have passed away.

The waqf concept is also well managed by non-Muslims in western countries; they named it an endowment. Many well-known universities in the world have endowments. The endowment is used for more sustainable educational activities. Therefore, Muslims who have the concept of waqf from ancient times must also manage waqf properly. All Muslims believe in the greatness of waqf because it is sourced from the Qur'an and authentic hadiths. This belief is a social capital that can be used to develop waqf movements and waqf foundations.

The second priority is the high potential for waqf in Indonesia. The country with an immense Muslim majority in the world has 420 thousand land waqf locations. This number is the largest in the world. Fauzia et. al. (2016) states that in 2010, waqf land data recapitulation throughout Indonesia showed 415,980 land waqf locations, and it increased to 435,395 sites of waqf land in 2013. The increase was also seen in the cash waqf. BWI first initiated it in 2010 with a total of IDR2 billion. In 2016, the total collected waqf funds amounted to IDR 185 billion.

This high potential for waqf is essential. The small potential impacts the difficulty of waqf development, while the great potential will facilitate waqf development and the organization of managing waqf. The enormous potential allows for the extensive collection of waqf so that the waqf organization can do something extraordinary. For example, if it is assumed that the average price of forest land in Indonesia is IDR20,000 $\mathrm{m}^{-2}$, then IDR 1 trillion will develop 5,000 ha of waqf forest. Looking at the experience of managing zakat in Indonesia, about 15 years ago, the zakat collection was only in the tens of billions. Currently, the assemblage of zakat has approached IDR8.1 trillion (USD549.8 million), with an

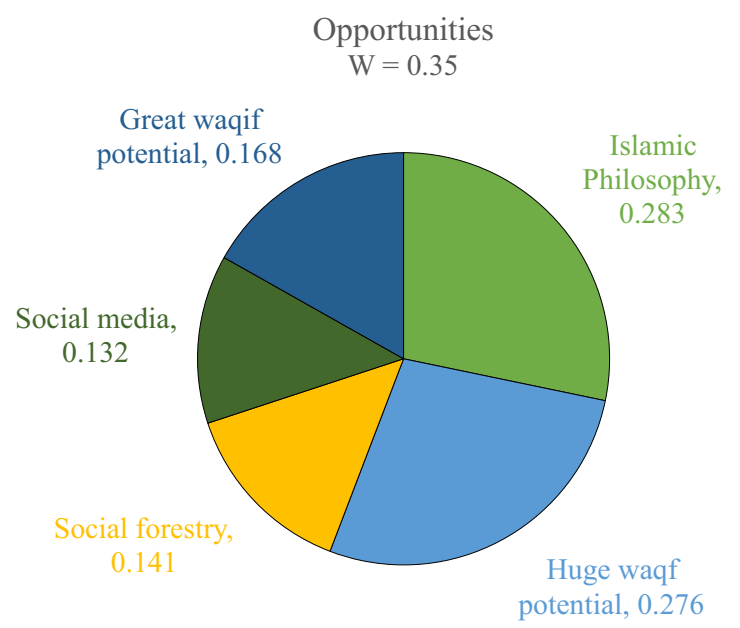

Figure 4 Priority among the opportunities aspects. average collection growth of $25.6 \%$ for the last five years (BAZNAS, 2019).

The third biggest opportunity is the enormous potential of waqf in Indonesia, which has the largest Muslim population globally. Indonesian Muslims are religious. The majority $(99 \%)$ of Indonesians who are predominantly Muslim consider religion to be essential in their lives (Crabtree, 2010). In general, Indonesians are more prosperous compared to the past. Moreover, the most important thing is that the Indonesian people are one of the most generous nations globally (CAF, 2018). These factors cause the high potential for waqif in Indonesia, as stated by Ali and Jannah (2019).

In the Act of the Republic of Indonesia Number 41 of 2004 on Waqf, a non-Muslim may perform endowments (becoming a waqif). Meanwhile, the nazir must be a Muslim. Therefore, the potential for wakif also becomes higher. Because not only by Muslims, endowments can also be fulfilled by non-Muslims. In the development of waqf forests, the possibility of waqif is crucial. The current development of waqf forests depends on waqif coming from the community, not the state. It is already known that the Indonesian government has a limited budget. The state budget for forest management is only USD4 ha ${ }^{-1}$ year $^{-1}$ (Herman, 2018). This amount is relatively smaller than the Malaysian government budget for forest management, which reaches USD18.5 ha $^{-1}$ year $^{-1}$ (Darori, 2012). However, if, in the future, the government has a better budget, the waqf forest is possible to be developed by the government. It can be established by both the central government and regional governments in the country.

Besides, waqf is related to waqf potential and other possibilities, such as the potential of human resources. Based on a survey conducted by the authors, most of the respondents were interested in participating in the waqf forest program. However, many do not have enough, so they cannot donate in the form of money. What they can do is to volunteer, to give attention and energy to the development of waqf forests. At present, the Bogor Waqf Forest Foundation has volunteers working for the development of waqf forests in Cibunian Village.

The fourth opportunity is a social forestry program. The social forestry program is the main program of the Indonesian government in the forestry sector. In this program, the Indonesian government gives people access to manage 13 million hectares of forest in the country. Until now, the realization of this program has reached more than 4 million hectares. The waqf forest program can synergize with social forestry programs. The waqf forest location managed by the Bogor Waqf Forest Foundation is directly adjacent to the "Taman Nasional Gunung Halimun Salak" (TNGHS) or Halimun Salak National Park. This waqf forest can play a role as a buffer zone for TNGHS. Based on an interview between the authors and the office manager of the national park, the Bogor Waqf Forest Foundation can work together with the TNGHS official manager. The foundation can use some part of the TNGHS land for community development, as long as in line with the national park mission.

The fifth opportunity is social media. Social media is the easiest way to spread a message to the broader community. Instagram, for example, is a platform that has been used by 
hundreds of millions of Indonesians. Almost all organizations have accounts on Instagram to have engagement with the community. The Bogor Waqf Forest Foundation already has an account on this platform. At present, the foundation account has been followed by more than 560 followers. To increase message dissemination, the foundation can promote each message by making payments to Instagram. The cost is relatively much cheaper compared to printing brochures, pamphlets, etc.

Despite having the lowest priority, it does not mean less important. The score is still above 13\%. On this basis, the Bogor Waqf Forest Foundation must also pay great attention to the use of social media, especially at certain times, such as during the Covid-19 outbreak.

Threats The unavailability of specific regulation is considered the most significant threat (Figure 5). At present, no law regulates waqf forests in Indonesia explicitly. It is regarded as a threat because it creates uncertainty over the status of waqf forests. According to the interview result, experts concluded that the absence of regulation raises two possibilities: the waqf forest program can continue, or this program might be banned in the future. Nevertheless, the chance of a second possibility is considered relatively small. Because according to $\mathrm{FN}$, the absence of specific regulations governing waqf forest does not mean that waqf forests are prohibited in state law. According to him, the current waqf regulations in Indonesia are flexible. He said waqf innovation is permitted in the available rules as long as it fulfills two conditions. First, the assets must remain available, and second, these assets are managed productively for the welfare of mauquf'alaihi. This is in line with a research by Jannah et al. (2020) which concluded that waqf forest can be legalized in Indonesia, as a part of waqf land utilization.

The unavailability of a fatwa on waqf forest is the second threat. The waqf forest program is relatively new, and it is unknown to the people of Indonesia. Waqf is known only in the form of places of worship, educational organizations, hospitals, or funerals (Huda et al., 2017). Therefore, fatwa regarding waqf forest becomes vital to convince the community that waqf forest is a program under sharia principles. However, the absence of a fatwa does not mean that waqf forests are not permitted in religion. All

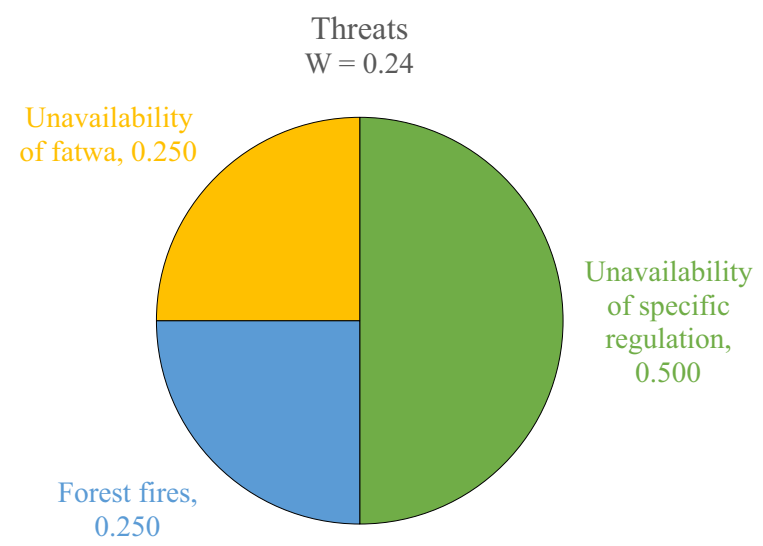

Figure 5 Priority among the threat aspects. respondents, including many experts in the Islamic economic sector, none of whom questioned the innovation of this waqf forest. Instead of it, all of them stated that this program was under sharia law. Although there is no waqf forest fatwa, there have been some fatwas related to the waqf forest. MUI, in this case, has issued several fatwas related to forest sustainability. For example, Fatwa of the Indonesian Ulema Council Number 04 of 2014 concerning the Conservation of Endangered Animals to Maintain Ecosystem Balance. This fatwa is in line with the manifestation of Islam as rahmatan lil 'alamin. The word 'alamin shows that Islam is not only compassion for Muslims or humans. Islam is a religion of affection for all of nature, namely for humans, animals, plants, and the environment. According to Al-Qaradhawi (2001), Muslims before have built waqf shelters specifically for abandoned dogs.

Forest fires are considered to be the third threat. Forest fires occur consistently in Indonesia frequently. These forest fires are often considered a disruption to the development of waqf forests. Once it happens, the waqf forests built can be destroyed immediately. However, forest fires are considered a smallest threat than other threats because forest fires almost always occur outside of Java (Sipongi KLHK, 2019). It does not mean that waqf forests can only be developed on the Island of Java. Waqf forests can also be established outside Java Island. However, the threat of waqf forest fires outside Java Island may be more significant. Some studies suggest that forest fires are related to oil palm plantations. An oil palm plantation company is suspected to be a forest-burning actor because burning forests is the cheapest and fastest way for land preparation (Rasyid, 2014). Cibunian waqf forest is located on Java Island, which is relatively safe from forest fires. Although there is a fire in the waqf forest, the land, which is an endowment asset, will not be lost. Waqf forest manager can build a new waqf forest in the area.

SWOT priorities The combined opinion of the experts shows that the most priority SWOT aspects to be considered in the development of waqf forest in Cibunian Village are the strength aspect $(35.6 \%)$, followed by opportunity $(32.6 \%)$, weakness (19.4\%), and threats (12.4\%) (Figure 6).

Kendall's coefficient (W) worth 0.79 . It indicates that respondents tend to agree on this matter. It shows that the Bogor Waqf Forest Foundation, as the manager of the Bogor waqf forest, should focus more on the aspects of strengths and opportunities rather than weaknesses and threats. Existing strengths need to be optimized in seizing available opportunities. It shows that the internal weaknesses of the foundation and external threats coming from outside the organization are considered less significant.

Strategies The combined opinion of the experts shows the priority of strategies that can be implemented in the development of the waqf forest in Cibunian Village. The highest mark is to get permission as waqf collector $(30.6 \%)$, followed by fundraising intensification $(24.9 \%)$, encouraging the issuance of waqf forest fatwa $(23.5 \%)$, and volunteer recruitment $(21.1 \%)$ (Figure 7$)$. Kendall's coefficient (W) worth 0.09 . It shows that the agreement among the experts is low. 
The highest priority among the strategies is still related to legal aspects. Based on the SWOT analysis, the Bogor Waqf Forest Foundation is an official foundation recognized by the state (S2); however, this foundation does not yet have permission to collect waqf/cash waqfs (T2). The absence of this permit means that the foundation does not yet have the right to raise the community's cash waqf. This permit absence could potentially be an issue in the future. Therefore, the permit must be completed immediately. The foundation, as an official institution recognized by the state, can more easily meet the process. Having an official permit from the authorities as an official waqf collector has many benefits for the foundation. The foundations will gain more trust from the communities.

The second priority strategy is fundraising intensification. This is a strategy built by utilizing the power to seize opportunities is called an aggressive strategy (Czajkowska, 2016). Based on SWOT analysis, the foundation's management, mostly alumni and lecturers of IPB University (S1) and state-recognized organizations (S2), can create a good reputation from the community perspective. A good reputation can lead to public trust. People who believe in an institution tend to donate to the trusted foundation rather than donate to the untrusted foundation. This power needs to be utilized for fundraising activities by using the role of information technology $(\mathrm{O} 2)$ to explore the potential of waqf (O3) and waqif (O4) in Indonesia. If this strategy can be implemented, institutions' weaknesses with limited financial resources (W3) can be resolved. The strategy is still closely related to the first strategy because, without the first strategy, the second priority strategy cannot be executed properly. Without permission from the government, the foundation is not allowed to collect money waqf from the public. Also, the availability of permits has an impact on the effectiveness of fundraising. The absence of the license will make people doubt to participate in the development of waqf forest.

Fundraising intensification can be increased at certain moments. Among the right momentum for fundraising is in the month of Ramadhan because, in this month, Indonesian Muslims tend to become more generous (Rama, 2020). Ramadhan is the golden momentum of social organizations

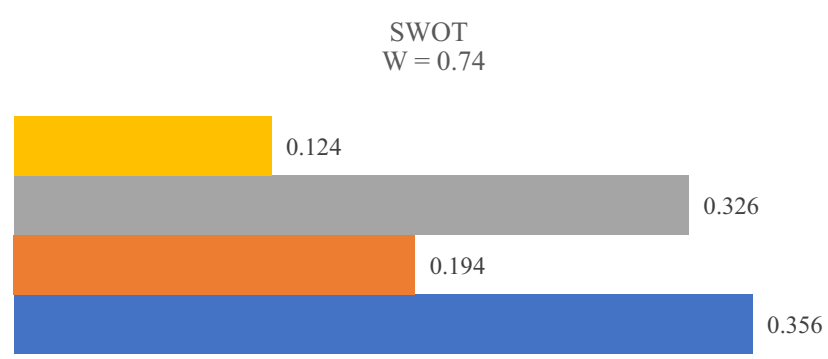

ahreats $\square$ Opportunities $\square$ Weaknesses $\square$ Strengths in Indonesia. It is due to two reasons. First, God will give a double reward for those who donate their money for the sake of Allah. Secondly, many Indonesians pay zakat in the month of Ramadan. Therefore, the Bogor Waqf Forest Foundation needs to optimize the momentum of Ramadan in its fundraising activities.

The third priority strategy is encouraging the issuance of waqf forest fatwa. This is a ST Strategy, a strategy developed by utilizing the power to overcome existing threats. This strategy is also called the conservative approach (Czajkowska, 2016). In the SWOT analysis, foundation administrators have a good network with IPB University and Baznas. It is also known that several IPB University lecturers are members of MUI. Therefore, the close relationship between the foundation and IPB University is a strength that can be utilized by the Foundation to encourage MUI as an institution that has fatwa authority to issue fatwas related to waqf forest (T1). Fatwa about waqf forest is essential for two reasons. First, the waqf forest fatwa will confirm that the waqf forest program is in line with sharia law. Second, waqf forest fatwa will dispel doubts in the hearts of people who are still doubtful about the program. It can be understood because the waqf forest is a relatively new waqf program in society.

The last priority strategy is volunteer recruitment. This strategy is a SW Strategy, a strategy developed to overcome existing weaknesses using available strengths. One of the foundation's weaknesses is human resources' unavailability who work full time (W1). One of the impacts is the foundation's licensing process in getting permission to collect cash waqf is hampered (W2). Also, the limited human resources cause fundraising activities to run slowly (W3). In overcoming these weaknesses, a foundation that has a good network with IPB University and Baznas (S3) can work together in providing volunteers who can help planned programs. It might be done because IPB University, as one of Indonesia's most prominent universities, has many reliable human resources, especially students. Although considered as the last priority, it is crucial because human resources are the main elements of an organization. Without proper human resources, an organization cannot develop properly (Rubel, 2019). Moreover, limited funds have caused the foundation

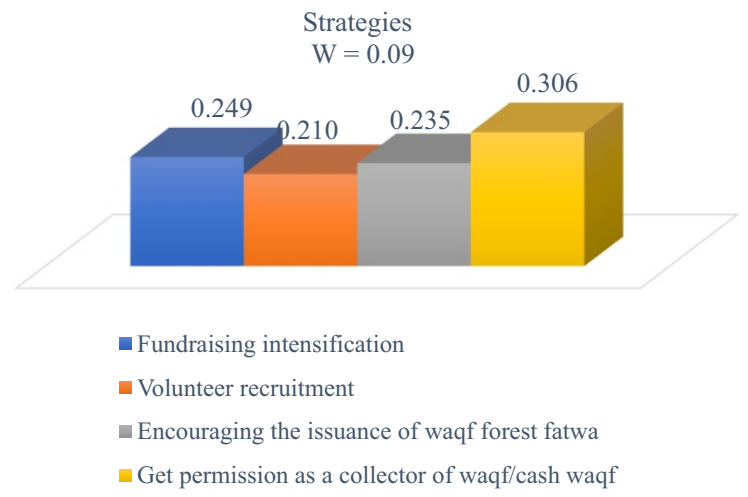

Figure 7 The priority of strategies of waqf forest development. 
to be unable to hire professional workers. That is why volunteering could be playing a role as a way out of this obstacle.

\section{Conclusion}

An aggressive strategy needs to be carried out by the Bogor Waqf Forest Foundation. It consists of maximizing its strengths to seize available opportunities by optimizing the existing legal organization and the well-educated human resources to educate the public about the concept of waqf in Islam and its application in the waqf forest. Thus, the massive potential of cash waqf and waqif can be obtained. The Bogor Waqf Forest Foundation as a waqf manager; however, has to pay attention to the main weakness. Namely, the foundation does not have a complete legal aspect. Therefore, the primary strategy in developing this foundation is to complete all legality related to waqf management to comply with the waqf management regulations, namely, Act No 41 of 2004 on Waqf.

\section{Recommendation}

As a waqf manager, Bogor Waqg Forest Foundation needs to immediately resolve the legal aspects required to become an official waqf manager in the Republic of Indonesia. It is crucial because the absence of a legal aspect causes waqf management activities carried out by the foundation to become illegal. Resolving this legal aspect will also make the foundation more trusted by the community. After the legal aspects are addressed, the Bogor Waqf Forest Foundation can intensify its fundraising activities by socializing Islamic teachings that motivate people to do waqf, primarily to participate in the development of waqf forests, which also have a high priority in Islam.

Next, the government needs to issue regulations regarding waqf forests. Also, to accelerate the development of waqf forests, the government, especially the Ministry of Religion of the Republic of Indonesia, can collaborate with waqf forest managers in various regions, especially with the Bogor Waqf Forest Foundation. This collaboration signifies that the waqf forest program is an innovation in waqf development that aligns with the country's applied waqf regulations.

After this, the Indonesia Ulema Council (MUI) needs to issue a fatwa or sharia opinion on waqf forest law. It is crucial to ensure that the waqf forest program is under Islamic law. It is to anticipate people who are still in doubt about the validity of the waqf forest, which is a relatively new program in the community.

Last, this is the challenge for waqf managers in Indonesia is to develop waqf assets productively. Future studies can examine models of productive waqf forests, so that waqf forests can provide social and ecological benefits and provide economic benefits, particularly in optimizing the benefits of non-timber forest products such as honey fruits and ecotourism.

\section{References}

Abu-Dawud. (2008). English translation of Sunan Abu Dawud. Riyadh: Darussalam Publishers.
Al-Anzi, E., \& Al-Duaij, N. (2004). Islamic waqf and environmental protection. Codicillus, 45(2), 52-63.

Al-Qaradhawi, Y. (2001). Ri'ayatul biiah fii syarii'atil Islam. Dar Al-Syuruq. https://www.al-qaradawi.net/ sites/default/files/pdf/8f24b-reaait-elbeaa-fi-alislam.pdf

Ali, K. M. (2019). Hutan wakaf : Solusi melestarikan rimba. Forest Digest, 12, 54-55.

Ali, K. M., \& Jannah, M. (2019, August 22). Model pengembangan hutan wakaf. Republika.

Ali, K. M., \& Kassim, S. (2020). Waqf forest: How waqf can play a role in forest preservation and SDGs achievement? Etikonomi: Jurnal Ekonomi, 19(2), 349-364. https://doi.org/10.15408/etk.v19i2.16310

Ali, K. M., Yuliani, M., Mulatsih, S., \& Abdullah, Z. (2018). Aspek-aspek prioritas manajemen wakaf di Indonesia. AL-FALAH: Journal of Islamic Economics, 3(1), 1. https://doi.org/10.29240/jie.v3i1.345

Ali, M. M., Devi, A., Furqani, H., \& Hamzah, H. (2020). Islamic financial inclusion determinants in Indonesia: An ANP approach. International Journal of Islamic and Middle Eastern Finance and Management, 13. https://doi.org/10.1108/IMEFM-01-2019-0007

Alisjahbana, A. S., \& Busch, J. M. (2017). Forestry, forest fires, and climate change in Indonesia. Bulletin of Indonesian Economic Studies, 53(2), 111-136. https://doi.org/10.1080/00074918.2017.1365404

Arredondo-soto, K. C., Realyvasquez-vargas, A., Maldonado-macías, A. A., \& García-alcaraz, J. (2019). Impact of human resources on remanufacturing process, internal complexity, perceived quality of core, numerosity, and key process indicators. Robotics and Computer Integrated Manufacturing, 59, 168-176. https://doi.org/10.1016/j.rcim.2019.04.004

As-Sa'di, A. (2002). Manhaju Al-Salikin. Ar-Rayyan: Dar Al-Wathan.

Ascarya. (2005). Analytic network process (ANP): Pendekatan baru studi kualitatif. Jakarta: Universitas Trisakti.

Ascarya. (2012). Analytic network process (ANP): Pendekatan baru dalam penelitian kualitatif. Bogor: STEI TAZKIA.

[BAZNAS] Badan Amil Zakat Nasional. (2019). Statistik zakat nasional 2018. Jakarta: BAZNAS

Budiman, M. A. (2011, May 2011). The role of waqf for environmental protection in Indonesia [Conference presentation]. Aceh Development International Conference 2011, Indonesia.

[BWI] Badan Wakaf Indonesia. (2010). Muhammadiyah 
canangkan gerakan wakafpohon. https://www.bwi.go.id/ 427/2010/03/berita/berita-wakaf/muhammadiyahcanangkan-gerakan-wakaf-pohon/

[CAF] Charities Aid Foundation. (2018). CAF world giving index 2018 (Issue October). https://www.cafonline.org/ docs/default-source/about-us-publications/ caf_wgi2018_report_webnopw_2379a_261018.pdf

Crabtree, S. (2010). Religiosity highest in world's poorest nations. In Gallup global reports (Vol. 2011, Issue March 31, 2011). Retrieved from http://www.gallup.com/ poll/142727/religiosity-highest-world-poorestnations.aspx $\% 5 \mathrm{Cn}$

Czajkowska, A. (2016). SWOT analysis application for indications of the strategy action chosen enterprise in the construction sector. Production Engineering Archives, 10,33-37. https://doi.org/10.30657/pea.2016.10.09

Darori. (2012). Anggaran konservasi hutan Indonesia masih terendah di dunia. Retrieved from https://nasional.kontan.co.id/news/anggaran-konservasihutan-indonesia-masih-terendah-di-dunia

Fauzia, A., Almuin, N., Rohayati, T., \& Garadian, E. A. (2016). Fenomena wakaf di Indonesia: Tantangan menuju wakaf produktif. Jakarta: Badan Wakaf Indonesia.

Gibson, C., Hardy, J. H., \& Buckley, M. R. (2014). Understanding the role of networking in organizations. Career Development International, 19(2), 146-161. https://doi.org/10.1108/CDI-09-2013-0111

Government Regulation Number 42/2006 concerning the Implementation of Law Number 41/2004 about Waqf.

Hasanah, I., \& Hakim, R. (2017). Pelestarian hutan kota melalui optimalisasi wakaf tunai. In Prosiding Seminar Nasional III Tahun 2017: Biologi, Pembelajaran, dan Lingkungan Hidup PerspektifIndisipliner (pp. 345-349).

Herman, K. (2018). Puji kinerja Siti Nurbaya, Komisi VII : Tidak mudah jadi Menteri LHK. Kementerian LHK. http://www.menlhk.go.id/siaran-64-puji-kinerja-sitinurbaya-komisi-vii-tidak-mudah-jadi-menteri-lhk.html

Hörnsten, L. (2000). Outdoor recreation in Swedish forestsImplication for society and forestry (dissertation). Silvestria: ActaUniversitatis Agricultyrae Sueciae. http://pub.epsilon.slu.se/12/

Huda, N., Rini, N., Mardoni, Y., Hudori, K., \& Anggraini, D. (2017). Problems, solutions, and strategies priority for waqf in Indonesia. Journal of Economic Cooperation and Development, 38(1), 29-54. Retrieved from http://repository.yarsi.ac.id/index.php/doc/ article/download/59/43/

Hutan-tersisa. (2018). Skenario dan model konseptual hutan wakaf. https://www.hutan-tersisa.org/p/skenario-danmodel-konseptual-hutan.html
Indraswari, D. L. (2020, January 8). Darurat pengelolaan hutan Indonesia. Kompas. https://kompas.id/ baca/utama/2020/01/08/darurat-pengelolaan-hutanindonesia/? $\mathrm{t}=$ AUAEdWFtx0N5G9LLeL TILTrgAnCUi w7Xb95dHkaDOxFM3rqF4G6aef4P192hA1

Jannah, M., Sarkawi, A. A., \& Othman, J. (2020). Legalization of waqf forests in Indonesia: A registration process. Indonesia Law Review, 10(3). https://doi.org/ 10.15742/ilrev.v10n3.629

Khotimah, B. K., Irhamni, F., \& Kustiyahningsih, Y. (2017). Integration fuzzy analytic network process (ANP) and SWOT business strategy for the development of small and medium enterprises (SME). AIP Conference Proceedings 1867, 020055. https://doi.org/10.1063/ 1.4994458

Khuza, R., Kurniati, N., Suhendi, H., \& Arif, M. F. (2019). Developing a waqf institution through repairment management and insitutional legalization. Advances in Social Science, Education and Humanities Research (ASSEHR), 307, 34-37.

Ozdemir, I. (2002). An Islamic approach to the environment. Environment-Ecology. http://www.environmentecology.com/religion-and-ecology/489-an-islamicapproach-to-the-environment.pdf

Qaradhawi, Y. (2001). Islam agama ramah lingkungan (Ri'ayatul biiah fii syarii'atil Islam). Jakarta: Pustaka AlKautsar.

Rama, A. (2020, May 21). Keep up the generosity beyond Ramadan. Jakartapost. https://www.thejakartapost.com/ academia/2020/05/21/keep-up-generosity-beyondramadan.html

Rastgoo, P. (2016). The role of human resources competency in improving the manager performance. Acta Universitatis Agriculturae et Silviculturae Mendeliane Brunensis, 64(1), 341-350.

Rasyid, F. (2014). Permasalahan dan dampak kebakaran hutan. Jurnal Lingkar Widyaiswara, 1(4), 47-59.

Rohmaningtyas, N., \& Herianingrum, S. (2010). The significance of waqf in historical and teoritical studies. Journal of Islamic Economics Science, 1(1), 39-55.

Rubel, M. (2019). The strength of human resources in organization. International Research Journal of Engineering and Technology (IRJET), 6(4), 2796-2799.

Saaty, T. L., \& Vargas, L. G. (2006). Decision making with the analytic network process. New York: Springer.

Saheeh International Translation. (2010). The Qur'an with surah introductions and appendices. In A. B. Al-Mehri (Ed.), Maktabah Booksellers and Publishers. http://quran.com/1 
Sahih Bukhari. (2009). Sahih Bukhari (M. M. Khan, Trans.; $1 \mathrm{st}$ ed.). ( 2009 ). S ahih Bukhari. https://d1.islamhouse.com/data/en/ih_books/single/ en_Sahih_Al-Bukhari.pdf

Sahih Muslim (A. A. H. Siddiqui; Trans). (2009). Sahih Muslim.

Setyorini, S. N., Wirdyaningsih, \& Hazna, C. A. (2020). Wakaf lingkungan hidup dalam rangka pelaksanaan pembangunan berkelanjutan dan penegakkan keadilan antargenerasi. Journal of Islamic Law Studies, Sharia Journal, 3(1), 98-132.

Seymour, F., \& Busch, J. (2016). Why forests? Why now? In Center for Global Development. Retrieved from https://www.cgdev.org/sites/default/files/why-forestswhy-now-10-14-14_0.pdf

Shafiai, M. H. M., Moi, M. R., \& Ahmad, R. (2015). The potential of waqf in activating idle agricultural land. Jurnal Pengurusan, 44, 141-147. https://doi.org/ 10.17576/pengurusan-2015-44-13

Sipongi KLHK. (2019). Rekapitulasi luas kebakaran hutan dan lahan (ha) per provinsi di Indonesia Tahun 20142019. Sipongi.http://sipongi.menlhk.go.id/pdf/luas_kebakaran

Tuckman, B. W., \& Jensen, M. A. C. (1977). Stages of smallgroup development revisited. Group \& Organization Studies, 2(4), 419-427. https://doi.org/10.1177/ 105960117700200404

Yaakob, A., Mahzir, N., Supaat, D. I., Zakaria, M. Z., Wook, I., \& Mustafa, M. (2017). Waqf as a means of forest conservation: Alternative for Malaysia. Advanced Science Letters, 23(5), 4860-4864. https://doi.org/ 10.1166/asl.2017.8928

Yamamoto, Y., Shigetomi, Y., Ishimura, Y., \& Hattori, M. (2019). Forest change and agricultural productivity: Evidence from Indonesia. World Development, 114, 196-207. https://doi.org/10.1016/j.worlddev.2018.10. 001 